\section{Biological Variation of Procalcitonin in Healthy Individuals}

\section{To the Editor}

Procalcitonin (PCT) is a stable 116amino acid precursor molecule to the hormone calcitonin. High serum concentrations have been reported in patients with severe systemic bacterial or fungal, but not viral, infections (1).

Information on the biological variation of PCT is not available; this is limiting because the clinical utility of laboratory data can be affected by physiologic variation (2). Here we report the results of a study to determine the biological variation of PCT.

To investigate the biological variation of this analyte, we followed the same protocol that we used for the study of the biological variation of N-terminal pro-B-type natriuretic peptide (3). We took five blood specimens from each of 16 apparently healthy laboratory workers (5 men and 11 women; age range, 43-62 years) twice a week (Tuesdays and Fridays) over a 17-day period. None of the workers smoked, took any medication, or consumed substantial quantities of alcohol. In accordance with Helsinki Declaration II, the design and execution of the experiment were explained thoroughly to the participants, and informed consent was obtained. Blood was collected under standardized conditions to minimize sources of preanalytic variation. After an overnight fast, a blood specimen was taken by conventional venipuncture between 0800 and 0900 with the volunteers in the sitting position, avoiding venous stasis. All samples were drawn by the same phlebotomist, allowed to clot, and then centrifuged at $3000 \mathrm{~g}$ for $15 \mathrm{~min}$ at room temperature within $1 \mathrm{~h}$ from collection. Sera were separated and stored at $-70^{\circ} \mathrm{C}$ until analysis.

At the end of the collection period, all frozen samples were thawed, mixed, and centrifuged for analysis in a single run in duplicate. PCT concentrations were determined by the time-resolved amplified cryptate emission (TRACE) methodology on Kryptor (Brahms Diagnostic) by the same analyst, who followed the assay manufacturer's recommendations. The mean PCT concentrations for men and women were not different $(P=0.93)$. The analytical $\left(\mathrm{CV}_{\mathrm{A}}\right)$ and intra- $\left(\mathrm{CV}_{\mathrm{I}}\right)$ and interindividual $\left(\mathrm{CV}_{\mathrm{G}}\right)$ components of variation were calculated by nested ANOVA. The reference change value (RCV) for significant changes in serial results $(P$ $<0.05$ ), the index of individuality, and the desirable quality specifications for imprecision (I), bias (B), and total error (TE) were calculated using the following formulae:

$$
\begin{gathered}
\mathrm{RCV}=2^{1 / 2} \times 1.96 \times\left(\mathrm{CV}_{\mathrm{A}}^{2}+\mathrm{CV}_{\mathrm{I}}^{2}\right)^{1 / 2} \\
\mathrm{I}<0.5\left(\mathrm{CV}_{\mathrm{I}}\right) \\
\mathrm{B}<0.25\left(\mathrm{CV}_{\mathrm{I}}^{2}+\mathrm{CV}_{\mathrm{G}}^{2}\right)^{1 / 2} \\
\mathrm{TE}<1.65 \mathrm{I}+\mathrm{B}(\alpha<0.05) .
\end{gathered}
$$

The number of specimens that should be collected to estimate ( $P$ $<0.05)$ the homeostatic set point of an individual within $\pm 10 \%\left[1.96^{2} \times\right.$ $\left.\left(\mathrm{CV}_{\mathrm{A}}^{2}+\mathrm{CV}_{\mathrm{I}}^{2}\right) / 100\right]$ was also evaluated. The results are reported in Table 1 .

The TRACE precision assay does not meet the goal [neither the desirable nor the minimum analytical pre- cision, $\mathrm{CV}_{\mathrm{A}} \leq 0.50\left(\mathrm{CV}_{\mathrm{I}}\right)$ and $\mathrm{CV}_{\mathrm{A}}$ $\leq 0.75\left(\mathrm{CV}_{\mathrm{I}}\right)$, respectively] based on biological variation, at least at the concentrations measured in our population. The error added to clinical signal through analytical noise is $37 \%$ (2). Improvement is therefore required if this assay is to be offered on a routine basis. Finally, the low index of individuality shows that the use of population-based reference limits is inadequate for interpretation.

\section{References}

1. Assicot M, Gendrel D, Carsin H, Raymond J, Guilbaud J, Bohuon C. High serum procalcitonin concentrations in patients with sepsis and infection. Lancet 1993;341:515-8.

2. Fraser CG. Biological variation: from principles to practice. Washington: AACC Press, 2001 151pp.

3. Melzi d'Eril GV, Tagnochetti T, Nauti A, Klersy C, Papalia A, Vadacca G, et al. Biological variation of $\mathrm{N}$-terminal pro-brain natriuretic peptide in healthy individuals. Clin Chem 2003;49: 1554-5.

\section{Alessandra Barassi* \\ Francesco Pallotti GianVico Melzi d'Eril}

Dipartimento di Scienze Biomediche Sperimentali e Cliniche Università degli Studi dell'Insubria Varese, Italy

\footnotetext{
*Address correspondence to this author at: via Dunant 5, 21100 Varese, Italy. Fax 39-0332278565; e-mail alessandra. barassi@tin.it.
}

DOI: $10.1373 /$ clinchem.2004.037275

\section{False-Negative Result in the Detection of an IgM Monoclonal Protein by Capillary Zone Electrophoresis}

Table 1. Mean values; estimated mean analytical $\left(\mathrm{CV}_{\mathrm{A}}\right)$, intraindividual $\left(\mathrm{CV}_{\mathbf{l}}\right)$,

\begin{tabular}{|c|c|c|c|c|c|c|c|c|c|c|}
\hline Group & $\begin{array}{c}\text { Mean, } \\
\text { Mg/L }\end{array}$ & $\underset{\%}{C V_{A},}$ & $\underset{\%}{\mathbf{C V}_{\mathbf{l}}}$ & $\begin{array}{c}\mathbf{C V}_{\mathbf{G}} \\
\%\end{array}$ & $\mathrm{II}^{\mathrm{a}}$ & $\underset{\%}{\mathbf{R C V}}$ & $n^{b}$ & $\begin{array}{c}\text { Imprecision, } \\
\%\end{array}$ & $\begin{array}{c}\text { Bias, } \\
\%\end{array}$ & $\begin{array}{c}\text { TE, } \\
\%\end{array}$ \\
\hline All & 0.040 & 15 & 16 & 22 & 0.7 & 60.6 & 18 & 8.1 & 6.9 & 20.3 \\
\hline Men & 0.043 & 14 & 19 & 21 & 0.9 & 65.5 & 21 & 9.4 & 7.1 & 22.6 \\
\hline Women & 0.038 & 15 & 14 & 23 & 0.6 & 57.0 & 16 & 7.0 & 6.7 & 18.3 \\
\hline
\end{tabular}
and interindividual $\left(\mathrm{CV}_{\mathrm{G}}\right)$ variation; and derived indices for serum PCT.

Desirable quality specifications

a II, index of individuality.

${ }^{b}$ Number of specimens that should be collected to estimate the homeostatic set point of an individual.

\section{To the Editor:}

Capillary zone electrophoresis (CZE) of serum proteins has developed into a rapid and sensitive analytical technique that is gaining impact in clinical laboratories because of its suitability for automation $(1,2)$. We report a case of plasmacytic lymphoma with an IgM monoclonal gammopathy that was difficult to detect by CZE. 